\title{
女子ハンドボール選手の12分間走による尿中有機酸排出变動
}

\author{
小郷克 敏* 新 立 義 文** 野見山俊一*** \\ 松元尚大**** 緒方 昇* 井本岳秋*** \\ 瀬 井起生* 澤田芳 男*
}

\section{THE CHANGES IN URINARY ORGANIC ACIDS OF FEMALE HANDBALL PLAYERS AFTER 12-MINUTE RUNNING}

\author{
Katsutoshi Ogo, Yoshifumi Shindate, Shunichi Nomiyama, \\ Hisahiro Matsumoto, Noboru Ogata, Takeaki Inomoto, \\ Kisei Sei and Yoshio Sawada
}

\begin{abstract}
Fourteen female handball players who were candidates for Olympic representative team were asked to run 12 minutes, and the relationship between the variation of the urinary components and the variations of the running speed and the heart beats was researched.
\end{abstract}

The obtained results in short are in the following :

1) The covered distance of the 12-minute running was from 2,385 meters to 3,050 meters, and the average was $2,830 \pm 196.6$ meters.

2) The heart beat rate quickly recovered for about 5 minutes after running, and then gradually reduced; after 30 minutes the rate was considerably higher than the level before the running in many cases.

3) The urinary volume was obviously less after the running than that before it.

4) The 1-hour after urine including the running time contained much pyruvates and lactates exhausted therein, and then the excretion amount reduced to the previous level. The ratios of Pyruvic acid/Creatinine and Lactic acid/Creatinine showed similar tendencies. The ratio of Pyruvic acid/Creatinine before the running against that after the running showed positive correlation with the running speed more than $230 \mathrm{~m} / \mathrm{min}$., but showed a negative correlation clearly with the recovering rate of the heart beat after 30 minutes being higher than $60 \%$. It suggests that the excretion of urinary pyruvate increase with more anaerobic factors for energy production under the conditions of the higher speed running and the larger oxygen debt.

5) The urinary citrate obviously decreased just after the running, but in recovered considerably in the urine obtained after 2 hours. The ratio of Citric acid/Creatinine was low just after the running. The variations appears not to be simply due to the reduction of renal clearance.

6) The urinary creatinine tended to reduce in the urine obtained 1-hour after the running, and particularly with the urinary pyruvate more than $50 \mu \mathrm{g} / \mathrm{ml}$ there was observed clear negative correlation with creatinine which showed lower concentration with more anaerobic factors; it suggests some reduction of renal clearance.

(J. Physical Fitness Japan 1978, $27: 64 \sim 72$ )

* 熊本大学体質医学研究所

** 熊本紧站教育センター

$* * *$ 㸃本部科大学

**** 熊本人学教養部保健体育
Department of Morphology, Institute of Constitutional Medicine, Kumamoto University.

Kumamoto Research Center for Education.

Kumamoto University of Commerce.

Department of Health and Physical Education, Faculty of General Educa-

tion, Kumamoto University. 
生体に運動を負荷した場合，その運動を遂行す るには個体差があるものと思われる。この差の中 にはエネルギー供給の質的な差異あ含まれてい る。つまり，有酸素的部分之無酸素的部分があ り，それらが占める比率に差があることはよく知 られたととである7゙。一般に身体作業能力を規定 する屯のとして最大酸素掑取量があげられてお り，てれが，個人の持続的作業能をあらわす指標 であることは常識とされている。しかし，ほとん ど同程度の最大酸素摂取量を持ちながら競技記録 の大きく異なることのある(10) ことも事実であり， これは無酸素的作業能に負うとてろが大きいこと は十分考えられることである。

そこで今回は, 一流女子ハンドボール選手の作 業能力を测るため12分間走を実施し，その前後の 尿中ピルビン酸 (pyruvic acid; pyruvate あるい はPyr と略記する),クエン酸 (citric acid ; citrate あるいは Cit と略記する)，乳酸 (lactic acid； lactate あるいは Lac と略䛉する）およびクレア チニン (creatinine あるいは Creat と略記する) の排出変動を調べ, 走速度, 脈拍変動との関係と ともに，腎機能の変化状況の検討を試みた。

\section{研 究 方 法}

1. 被験者および測定時期

被験者は全日本ハンドボールチームに所属する 20歳から25歳までの女子選手14名で，1976年モン トリオール・オリンピックに出場する日本代表チ 一ムの候補選手のうち12分間走テストを実施した 者である。12分間走テストは1976年 4 月15日の忚 前中に熊本県山鹿市熊本県立教育センター内のア

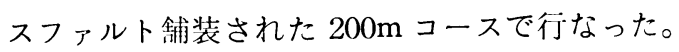

Table 1. The physical profiles of subjects

\begin{tabular}{rl|c|c|c}
\hline \multicolumn{2}{c|}{ Subject } & $\begin{array}{c}\text { Age } \\
\text { (years) }\end{array}$ & $\begin{array}{c}\text { Height } \\
(\mathrm{cm})\end{array}$ & $\begin{array}{c}\text { Weight } \\
(\mathrm{kg})\end{array}$ \\
\hline 1. & S.W. & 24 & 167.6 & 73.8 \\
2. & H. K. & 25 & 151.6 & 49.8 \\
3. & N. S. & 25 & 162.5 & 56.7 \\
4. & A. K. & 25 & 162.0 & 56.5 \\
5. & M. K. & 21 & 163.1 & 64.0 \\
6. & E. Y. & 23 & 159.7 & 60.1 \\
7. & H.M. & 21 & 162.8 & 62.4 \\
8. & E. K. & 20 & 167.3 & 72.5 \\
9. & N.K. & 23 & 161.3 & 60.0 \\
10. & N. K. & 20 & 165.2 & 65.1 \\
11. & H. O. & 21 & 163.8 & 63.5 \\
12. & H.W. & 23 & 159.9 & 64.1 \\
13. & H. S. & 23 & 170.1 & 68.2 \\
14. & K. K. & 21 & 165.6 & 65.9 \\
\hline
\end{tabular}

各被験者の身長，体重および年柃は表 1 亿示すと おりである。

\section{2. 脈拍数測定}

脈拍数は安静時および走後各時期とも各被験者 ごとに用手法で测定した。

\section{3. 採尿時期および尿中成分測定}

被験尿は図 1 亿示すとおり，12分間走テスト前 に安静時尿を, 回復時尿としてはテスト後 1 時間 目と 2 時間目にそれぞれ採取した。

尿中 pyruvate $は 2,4$-dinitrophenylhydrazone とし, xylene で抽出を行う力法5で测定した。

尿中 citrate は G.B. Jones ${ }^{1)}$ のj法を若干改変 した方法6)で測定した。

尿中 lactate は乳酸脱水菜酵素と $\beta$-NAD を用 い紫外部吸收の変化による力法によって测定し た。

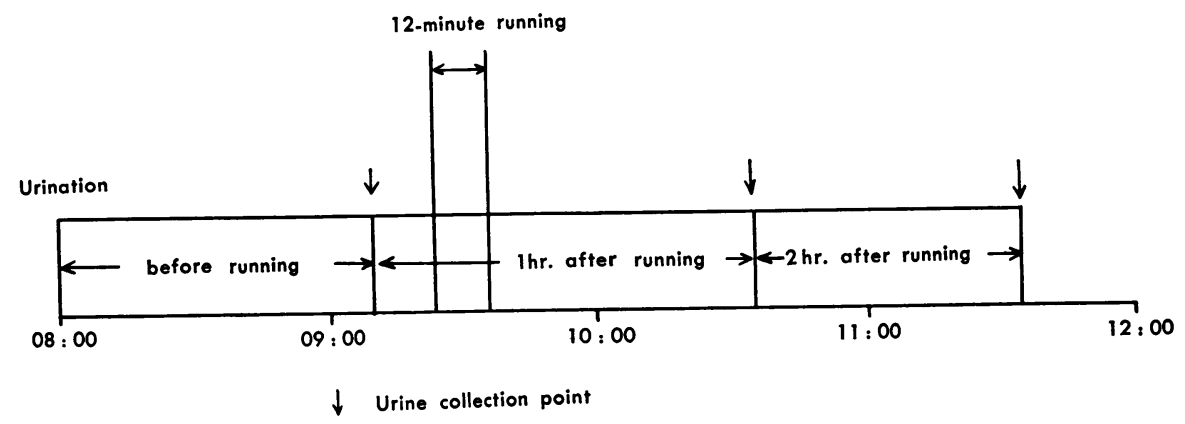

Fig. 1 Time schedule for collection of urine 
尿中 creatinineはピクリン酸を用いる方法によ って測定した。

\section{成 綡}

1. 12分間走距離について

各被験者の12分間の走距離および平均速度は表 2 に示すとおりである。被験者番号12，13および 14はひざや腰に若干の故障を訴えている。故障の ない11名については Cooper ${ }^{7}$ の体力区分でVの ランクにあり，そのうち9名は男性の体力区分で みてもVのランクに入っていて，かなり速いスピ ードで走っている。

Table 2. Distance in meter covered in 12 minutes

\begin{tabular}{|c|c|c|c|c|}
\hline Subject & $\begin{array}{l}\text { Distance } \\
(\mathrm{m})\end{array}$ & $\begin{array}{l}\text { Average } \\
\text { speed } \\
(\mathrm{m} / \mathrm{min})\end{array}$ & Rank by & Cooper ${ }^{7}$ \\
\hline 1. S.W. & 2885 & 240.4 & $\left.\mathrm{~V}^{* 1}, \mathrm{n}\right)$ & $\mathrm{V}^{* 2}$ \\
\hline 2. H. K. & 2932 & 244.3 & V & V \\
\hline 3. N. S. & 3050 & 254.2 & V & $\mathrm{V}$ \\
\hline 4. A. K. & 3000 & 250.0 & $\mathrm{~V}$ & $\mathrm{~V}$ \\
\hline 5. M. K. & 2870 & 239.2 & V & V \\
\hline 6. E.Y. & 3000 & 250.0 & $\mathrm{~V}$ & $\mathrm{~V}$ \\
\hline 7. H.M. & 3027 & 252.3 & $\mathrm{~V}$ & V \\
\hline 8. E. K. & 2840 & 236.7 & $\mathrm{~V}$ & V \\
\hline 9. N. K. & 2970 & 247.5 & $\mathrm{~V}$ & $\mathrm{~V}$ \\
\hline 10. N. K. & 2790 & 232.5 & V & IV \\
\hline 11. H. O. & 2780 & 231.7 & $\mathrm{~V}$ & IV \\
\hline 12. H.W. & 2548 & 212.3 & $I V^{(1)}$ & IV \\
\hline 13. H. S. & 2548 & 213.3 & IV & IV \\
\hline 14. K. K. & 2385 & 198.8 & IV & III ' ) \\
\hline $\begin{array}{l}\text { Mean } \\
\quad \pm \text { S.D. }\end{array}$ & $\begin{array}{r}2830.4 \\
\quad \pm 196.6\end{array}$ & $\begin{array}{r}235.87 \\
\quad \pm 16.38\end{array}$ & V & V \\
\hline
\end{tabular}

${ }^{* 1}$ : Fitness category for women (under 30 years of age)

*2 : Fitness category for men (under 30 years of age)

a) : Excellent, Ł) : Good, c) : Fair

\section{2. 脈拍の変化について}

12分間走後の脈拍数の変化は回復率として図 2 に示す。吅復摔は\{(正後 1 分目脈拍数一走後各時 期脈拍数/(走後 1 分目脈拍数一走前安静時脈拍 数) $\} \times 100$ で求めたものであり，30分後では91，\% から57.9\%の間にあり，问復状態に大きな差がみ られる。

3. 尿中成分排出量について

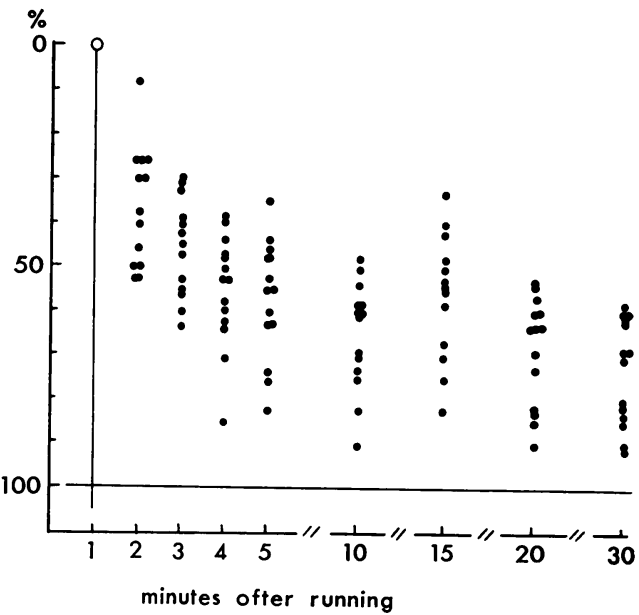

Fig. 2 Change in recovery rate of heart beat

Table 3. Changes of urinary substances before and after 12-minute running

$$
(\mathrm{n}=14)
$$

\begin{tabular}{|c|c|c|c|}
\hline $\begin{array}{r}\text { collection } \\
\text { period }\end{array}$ & Before & After $\mathrm{ru}$ & anning \\
\hline & running & $\sim 1 \mathrm{hr}$ & $1 \sim 2 \mathrm{hr}$ \\
\hline $\begin{array}{l}\text { Urine } \\
\text { volume } \\
(\mathrm{ml} / \mathrm{hr})\end{array}$ & $\begin{array}{r}57.66^{* *}, \cdots \\
\pm 19.49 \\
\end{array}$ & $\begin{array}{l}32.34^{* *} \\
\quad \pm 11.97 \\
\end{array}$ & $\begin{array}{c}\text { 41. } 14 \\
\pm\end{array}$ \\
\hline $\begin{array}{l}\text { Pyruvate } \\
(\mathrm{mg} / \mathrm{hr})\end{array}$ & $\begin{array}{l}1.01^{* *} \\
\pm 0.25\end{array}$ & $\begin{array}{l}* * 5.74^{*} \\
\quad \pm 4.60\end{array}$ & $\begin{array}{l}2.09^{*} \\
\pm 2.22\end{array}$ \\
\hline $\begin{array}{l}\text { Citrate } \\
(\mathrm{mg} / \mathrm{hr})\end{array}$ & $\begin{array}{c}76.34^{* * *} \\
\pm 34.71\end{array}$ & $\begin{array}{r}* * * 34.29 \cdots \\
\pm 22.10\end{array}$ & $\begin{array}{r}62.05 \cdots \\
\pm 23.09\end{array}$ \\
\hline $\begin{array}{l}\text { Lactate } \\
(\mathrm{mg} / \mathrm{hr})\end{array}$ & $\begin{array}{l}3.71^{* *} \\
\quad \pm 1.29\end{array}$ & $\begin{aligned} * * 87 & \pm 53 \cdots \\
& \pm 83.36\end{aligned}$ & $\begin{array}{l}7.51 \cdots \\
\quad \pm 10.00\end{array}$ \\
\hline $\begin{array}{c}\text { Creatinine } \\
(\mathrm{mg} / \mathrm{hr})\end{array}$ & $\begin{array}{l}49.30^{* *} \\
\quad \pm 13.78\end{array}$ & $\begin{array}{l}44.82^{* * *} * \\
\quad \pm 16.09\end{array}$ & $\begin{array}{l}* 63.87^{* * *} \\
\quad \pm 13.15\end{array}$ \\
\hline
\end{tabular}

Mean \pm S.D.

$* \ldots \mathrm{P}<0.05, \quad \cdot, * * \ldots \mathrm{P}<0.01$

$\cdots, * * * \ldots \mathrm{P}<0.001$ between same marks

尿中各成分の平均値と槽準偏差は表 3 および四 3 に示すとおりである。

尿量は走前で最も多く，起後各時期尿量之の間 にそれぞれ $1 \%$ の危険率で有意の善が認められ る。とくに走後 1 時間尿で人きく低下している。

Pyruvate は走後 1 時閒尿で非常に多量排出さ れ，2洔間後尿ではかなり回復している。走後 1 時間尿之走前尿では 1 \%, 走後 1 時間尿之 2 時問 尿との間には $5 \%$ \%伦険率で有意の差が認められ る。

Citrate は起後 1 㭙間尿で排出量は減少し 2 婃 

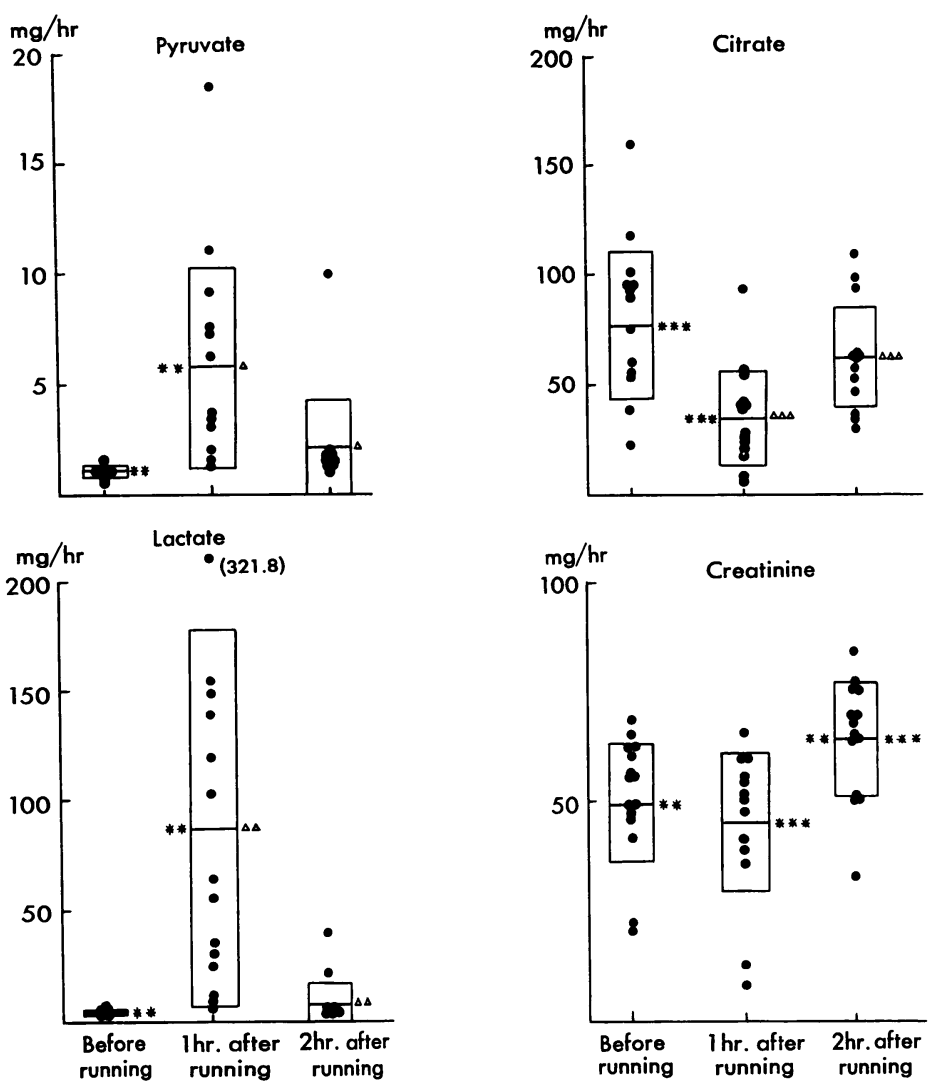

Fig. 3 Changes in excretion of pyruvate, citrate, lactate and creatinine in urine before and after 12-minute running test

間尿では回復している。歨後 1 時間尿と他の 2 時 期の尿との間にそれぞれ $0.1 \%$ の危険率で有意の 差が認められ，12分間走によって尿中 citrate は 明らかに減少することが浔められる。

Lactate は走後 1 時間尿で非常に多量排出され るが， 2 壯間後尿ではほとんど走前レベルに回復 している。走後 1 時間尿と他の 2 時剘尿との間に $1 \%$ の危険摔で有意の差が認めらる。

Creatinine 排出量は走後 1 時間尿では走削尿よ りわずかに減少する傾向がみられるが有意の差が あるとは認められない。しかし，走後尿ではかな

り多量の排出がみられる。走後 2 時間と走前尿之 の間には $1 \%$ の危険率で, 走後 1 侍間尿と走後 2 峙間尿との間には $0.1 \%$ の危険率で有意の差が認 められる。

4. 尿中成分の比について

各尿中成分比の平均值と標準偏差は表 4 および
Table 4. Changes of ratios before and after 12-minute running $(\mathrm{n}=14)$

\begin{tabular}{|c|c|c|c|}
\hline \multirow{2}{*}{$\begin{array}{r}\text { Collection } \\
\text { period } \\
\text { Ratios }\end{array}$} & \multirow{2}{*}{$\begin{array}{l}\text { Before } \\
\text { running }\end{array}$} & \multicolumn{2}{|c|}{ After running } \\
\hline & & $\sim 1 \mathrm{hr}$ & $1 \sim 2 \mathrm{hr}$ \\
\hline $\begin{array}{r}\text { Pyr/Creat } \\
(\mu \mathrm{g} / \mathrm{mg})\end{array}$ & $\begin{array}{r}* * * 20.91 \\
\pm 2.94\end{array}$ & $\begin{array}{r}* * * 146.06 \cdots \\
\pm 102.61\end{array}$ & $\begin{array}{r}30.87 \cdots \\
\quad \pm 24.85 \\
\end{array}$ \\
\hline Cit/Creat & $\begin{array}{r}* * * 1.599 \cdots \\
\pm 0.375\end{array}$ & $\begin{array}{r}* * * 0.735^{\circ 0 \circ} \\
\pm 0.316\end{array}$ & $\begin{array}{r}\cdots 0.921^{\circ 0 \circ} \\
\pm 0.368\end{array}$ \\
\hline Lac/Creat & $\begin{array}{l}0.087^{* *} \\
\pm 0.068\end{array}$ & $\begin{array}{r}* * 2.233 \cdots \\
\pm 1.767\end{array}$ & $\begin{array}{l}0.106 \cdots \\
\quad \pm 0.117\end{array}$ \\
\hline Lac/Pyr & $\begin{array}{c}* * * 4.15^{\circ} \\
\pm 3.00\end{array}$ & $\begin{array}{c}* * * 13.23 \cdots \\
\pm 5.45\end{array}$ & $\begin{array}{c}{ }^{\circ} 3.29 \cdots \\
\quad \pm 2.27\end{array}$ \\
\hline
\end{tabular}

Mean \pm S.D.

${ }^{\circ} . \mathrm{P}<0.05, * *, \cdots \ldots \mathrm{P}<0.01$, $* * *, \cdots,{ }^{\circ} \cdots \mathrm{P}<0.001$ between same marks

四 4 に示すとおりである。

Pyr/Creat は走後 1 時間尿では非常な高値を示 

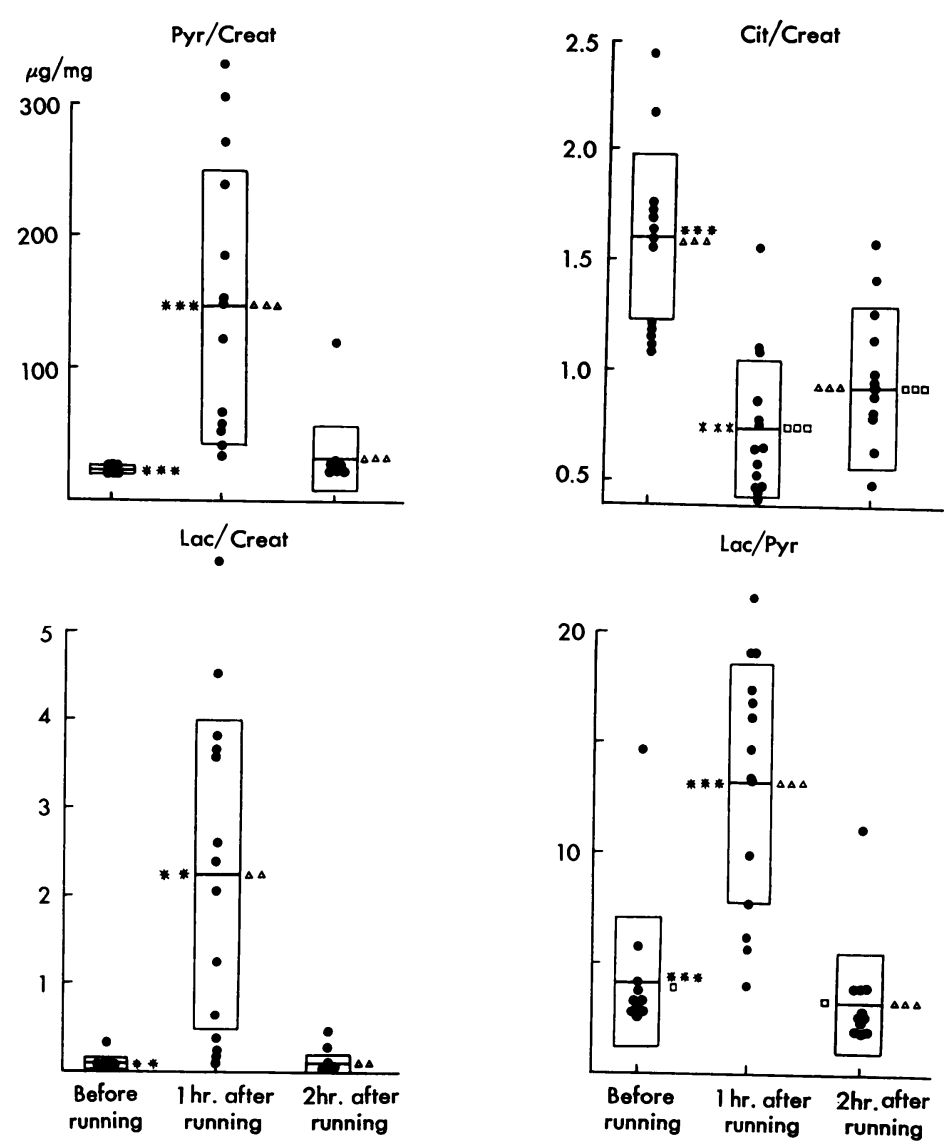

Fig. 4 Changes in ratios before and after 12 -minute running test

しており，止後 2 年開尿では回復の倾向を示して いる。延前尿と走後 2 咕間尿ならびに走後 1 時間 尿の間にはそれぞれ $0.10 \%$ の危険率で有意の差が 認められる。

Cit/Creat は走後 1 時間尿で最も低值であり, 他の 2 時期尿との間に0.1\%の危険率で有意の差

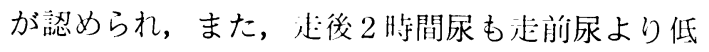
值で，この間にも $0.1 \%$ の伦険率で有意の差が認 めら机る。

Lac/Creat は走後 1 時間尿で非常に高い平均伹 を示しているが，分敬もかなり大きい。しかし， 他の 2 時期との間に 1900 危険率で有意の差が認 められる。走後 2 時間尿では走前レベルに回復し ている。

$\mathrm{Lac} / \mathrm{Pyr}$ は走後 1 時間尿で他の 2 时守期尿よりは るかに高值を示し，いずれとも $0.1 \%$ 先危険率で 有意の差が涩められる。また, 走後 2 洔問尿之走
前尿との間には $5 \%$ の危険率で有意の善が認めら れ, 赴後 2 時間尿では走前尿レベルより低い值を 示している。

\section{考察}

Cooper ${ }^{3)}$ により提唱され，いわ称る Endurance performance の指慓として広く行われている12分 間走を全日本ハンドボール女子チームの各被験者 に負荷し，各人がどのような作業の質で遂行して いるかを尿中成分の排出変動からとらえてみた。 嫌気的代謝の終末産物である pyruvate および lactate 之, 好気的代謝の過程である TCA サイク ル(クエン酸回路)の文字通りの基質である citrate の增減と，さらには腎クリアランスの内因性指標 として利用され，しかも，筋活動に関連性の深い creatinine の尿中への排出变動を調べ検討した。 表 3 および図 3 に示すように, pyruvate は走後 
1 時間尿では大きく上昇を示しているが，その增 加程度の分布は非常に広く，同じ12分間走を完成 するにも，いわゆる酸素負債の占める比率は広い 範囲に分布していることがうかがえる。

これらとは対照的に citrate は走後 1 時間尿で 急激な減少がみられ，12分間走運動に対するエネ ルギー供給が有酸素的なものに大きく依存してい ることからみても，血中 citrate は pyruvate や lactateのように蓄積しているとは考えられない。

また, creatinine の排出屯走後 1 時間尿で減少 する傾向があるが，乙の creatinine の排出減少は わずわなあのであり, citrateの減少程度よりはる かに小さな変化である。乙机は尿中 citrate の変 化が単に腎のクリアランスの低下だけによるもの ではないととを示唆している。さらに, 表 4 およ び闵 4 に示す Cit/Creat の変化をみても走後 1 時 間尿では他の時期より明らかに低いことが認めら れることからも, citrateは体内にあまり多量に蓄 積されるものではなく，さらに酸塩基平衡との関 係 ${ }^{11)}$ から尿への排出の減少となって現れているこ とを示唆している。

尿中 pyruvate や lactate 排出量は腎のクリア ランス能が低下しているにもかかわらず大きく増 加して抢り，体内の蓄積が非常に多いことがうか がえる。また，急激な運動によって血中 Lac/Pyr は上昇するとされている ${ }^{9)}$ が，12 分間走によって 尿中 $\mathrm{Lac} / \mathrm{Pyr}$ は明らかに上昇しており生体内の 缣気的状態をあらわしているむののようである。

尿中 pyruvate および lactate の排出量, ならび に，それぞれの creatinine との濃度比が止後に広 い範囲に分布しているのであるが，それらの代表 的な指慓として Pyr/Creat の上昇程度 (走後 1 時 閒/走前）と走スピードの関係をみると四 5 に示 すとおりである。230m/分以上のスピードでは Pyr/Creat はかなり高值を示しているが, 230m/ 分以下では比較的低值を示すようである。しか し,さらに遅いスピードではかえって比の上昇す る可能性もみられる。乙れは男子の10マイルロー ドレース時にみられる運動強度 $[\mathrm{m} / \mathrm{sec}] ・[\mathrm{~kg}]$ と Pyr/Creat の変化は変曲点をもつ 2 相性を示すと いう関係）とよく似たものである。

なお， $230 \mathrm{~m} /$ 分以上のスピードでは走スピード (X) と Pyr/Creat の前後比 $(Y)$ の相関係数は $\mathrm{r}=$

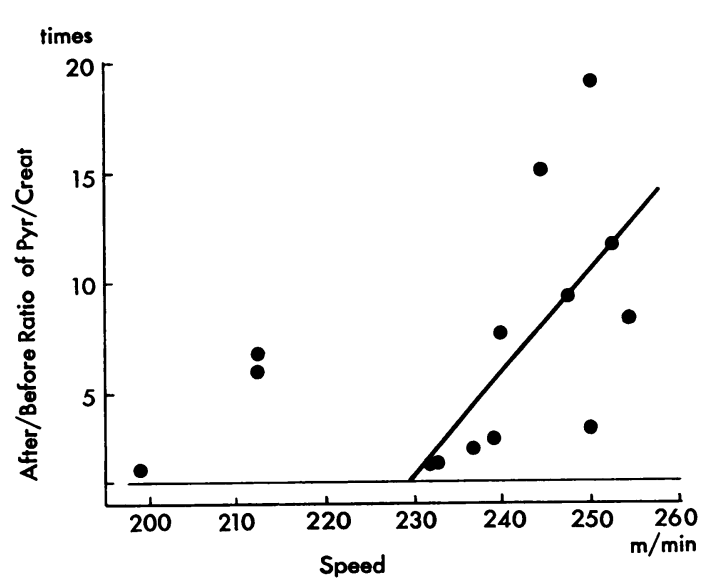

Fig. 5 Relation between running speed and increment (After/Before ratio) of Pyr/Creat

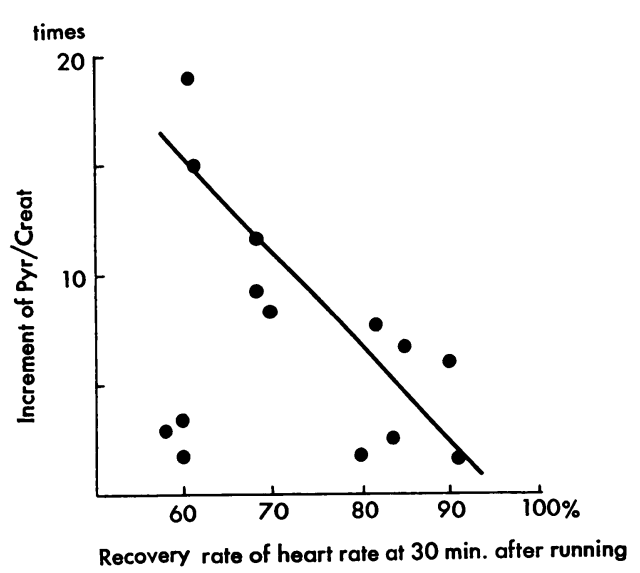

Fig. 6 Relation between recovery rate of heart beat and increment times of Pyr/Creat

$0.6295(\mathrm{P}<0.05)$, 回帰式は $Y=0.463 X-105.157$ で示される。

また, 12 分間走後 30 分の脈拍回復率之 $\mathrm{Pyr} /$ Creat の前後比との関係は図 6 に示すとおりであ る。これから,心拍の回復の悪いほうに Pyr/Creat の大きな上昇を示す者と小さな変化しか示さない 者とのはっきりした二つのグルーブのあることが わかる。回復率が $60 \%$ 以下の 3 例を除くと, 回復 率の高い者ほど Pyr/Creat の走前後における変化 は小さく，無酸素的作業の占める比率は少なくな るもののようである。回復率が60\%を越える11例 についての脈拍回復率: $(X)$ と Pyr/Creat 前後比 $(Y)$ の相関係数は $\mathrm{r}=-0.8527(\mathrm{P}<0.001)$, 回 帰式は $Y=-0.43 X+41.09$ で示される。 
以上のととから 12 分間走でも走スピードが速 く, 走後心拍の回復が遅い場合に尿中へ pyruvate や lactate の排出が增加している者があるように みられる。しかし, 走スピードとの関係図(図 5) からみられるとおり速度の上昇と直線的な関係に あるのではなく，ある器值をこえると急激に上昇 する傾向が認められ，無酸素的代謝琵値の高い者 が12分間走で好成績をあげているようである。

生体の無酸素的代謝の指滕としての pyruvate とこれと腎機能の一端を表わしているcreatinine との関係は図 7 に示すとおりである。

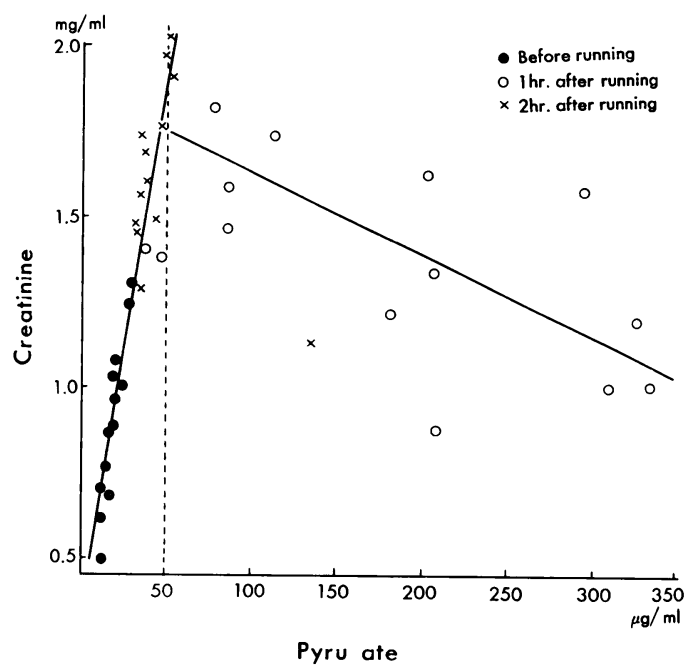

Fig. 7 Relation between pyruvate and creatinine concentration in urine before and after running

安静猔および走後 1 〜 時開尿では, ほとんよ゙ pyruvate 濃度は $50 \mu \mathrm{g} / \mathrm{ml}$ 以下であり，この籁囲 内では pyruvate 蒈度 $(X)$ と creatinine 濃度 $(Y)$ は相関係数 $\mathrm{r}=0.912(\mathrm{P}<0.001)$ で, 回帰式は $Y=0.031 X+0.338$ で示される強い正の相関閂係 が認められる。これらの時期では, 両指相の関係 は単純な尿の濃綰度によって規定されているよう である。しかし，走後 1 時間尿では pyruvate 濃 度はほとんど $50 \mu \mathrm{g} / \mathrm{ml}$ 以上であり，上記各時期 とは逆に pyruvate 濃度 $(X)$ が上昇するにつれて creatinine 濃度 $(Y)$ は低下する傾向がみられる。 pyruvate 濃度が $50 \mu \mathrm{g} / \mathrm{ml}$ 以上の15例では相関係 数は $\mathrm{r}=-0.699(\mathrm{P}<0.005)$, 回州式は $Y=-0.002$ $X+1.868$ で示される負の相関関係にあることが 認められる。通動によって高度に酸素不足の状態

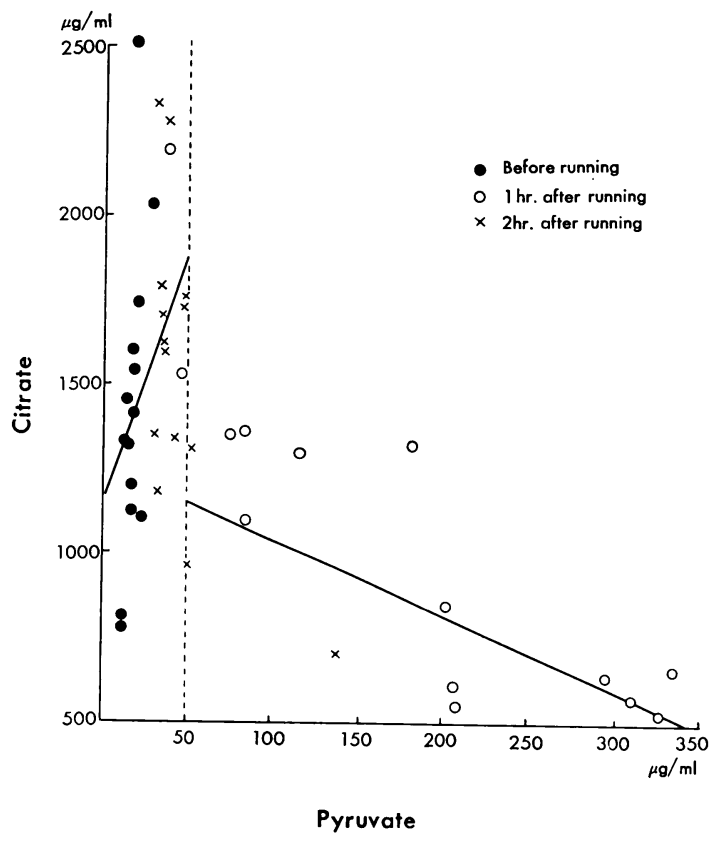

Fig. 8 Relation between urinary pyruvate and citrate

になった場合には筒の creatinine クリアランスが 抑庄:されることを示唆しているようである。

つぎに, 好気的代謝の代表的なもので, 生体の活 動エネルギーの大きな部分を供給している TCA 回路の直接の基質である citrate の尿中濃度之 pyruvate濃度の関係を調べた絬果は図 8 亿示すと おりである。

走㷙安静時尿では pyruvate 滥度の上昇ととも に citrate 濃度も上梨するような傾向がみられる。 しかし，12分間走後 1 時間尿では pyruvate 濃度 が上昇するにつれて citrate 濃度は低下する傾向 がみられる。前に述べた pyruvate と creatinine の関係と似ているが, creatinine は起後尿のほう が走前尿より高濃度であるととから, citrate濃度 が走前より走後に低下しており，単にクリアラン スの変化によるものだけではなく, 时らかに運動 によるエネルギー代謝系物質の変動の差や酸塩基 平衡の影響を受けているようである。

ここで，先に述べた pyruvate と creatinine の 関係と同様に pyruvate 濃度によって 2 群に分け て pyruvate $(X)$ と citrate $(Y)$ の関係をみると, まず, pyruvate が $50 \mu \mathrm{g} / \mathrm{ml}$ 未满の場合の相関係 数は $\mathrm{r}=0.376(\mathrm{P}<0.1)$, 回㷌式は $Y=14.220 X+$ 1170.151で示され，正相関の傾向がみられる。ま 
た, pyruvate が $50 \mu \mathrm{g} / \mathrm{ml}$ 以上の場合の相関係数 は $\mathrm{r}=-0.701(\mathrm{P}<0.005)$ ，回帰式は $Y=-2.244$ $X+1269.930$ で示され，明らかな負の相関関係が 認められる。

加賀谷 $\left.{ }^{2}\right)$ によると，酸素掑取量占有率が $2 / 3$ 以上 のランニングは約 6 分以上持続されるもので，陸 上競技の $5,000 \mathrm{~m}$ 競走からマラソンまで含まれる としているが，乙れは男子のトップランナーのも のであり，今回の女子ハンドボール選手では，こ れらより短い距離走に做するものと考えられ る。また，表 2 に示したとおり，平均速度はほと んどの者が約 $14 \mathrm{~km} /$ 侍から $15.2 \mathrm{~km} /$ 時の間にあ り，乙れは Margaria冬が示した乳酸性酸素负偵の 急激に增加する籁囲にある。このようなととか ら，体内の有酸素的代謝の基質である citrate に あまり大きな蓄積がなく無酸素的代謝の終米産物 である pyruvate の増加していることが尿中排出 変動としてあらわれていることは合理的であるよ うに考えらる。

\section{摘要}

オリンピック出場候補女子ハンドボール選手 14 名の12分間走前後にお打る尿中成分の変動と走速 度，脈拍数变動との関係などを検索し，つぎのよ うな結論を得た。

1） 12 分間の走行距離は $2385 \mathrm{~m}$ から $3050 \mathrm{~m}$ ま での籁囲にあり，平均值は $2830.4 \pm 196.6 \mathrm{~m}$ であ る。

2）走後の脈拍数の回復は 5 分頃までは速い が，以後は緩やかに低下し，30分後でも走前レベ ルよりかなり高い例が多い。

3）尿量は走前より走後に明らかな減少を示し ている。

4）尿中 pyruvate 㧍よび lactate は走行中を含 む 1 時間後尿で非常に多量排出され, 以後回復し ている。Pyr/Creat および Lac/Creat でみても同 様な傾向を示している。

尿中 Pyr/Creat の走前後比は走速度が $230 \mathrm{~m} /$ 分以上では走速度と正の相関関係を示し，30分後 の脈拍数回復率が $60 \%$ 以上では明らかな負の相関 関係が認められ，走速度が速く酸素負債が大きく てエネルギー産生に無酸素的要素が多いほど尿中 pyruvateの排出が多くなるととを示唆している。
5）尿中 citrate は走直後明らかな減少を示し， 2 時間後尿ではかなり回復している。

Cit/Creat でも走直後に低值を示しており，単 純な腎クリアランスの低下による变化ではなさそ うである。

6）尿中 creatinine は走後 1 洔間尿では減少す る傾问があり，とくに尿中 pyruvate が $50 \mu \mathrm{g} / \mathrm{ml}$ 以上では無酸素的要素が多くなるにつれて creatinine は低濃度を示す明らかな負の相関関係が認 められ，この状態に扔いては婜のクリアランスの 低下があるもののようである。

（要付 昭和53年 3 刀30日）

\section{文献}

1) G.B. Jones (1967) : Estimation of microgram quantities of citrate in biological fluids. Anal. Biochem., 21, 286-292

2）加賀谷熙彦 (1978)：エネルギー需給からみた running の特性。体育の科学, 28(1), 28-33

3) Kenneth H. Cooper (1970): The new aerobics, M. Evans and Company, New York

4）野見儿俊一。小郷克敏。沢目芳男(1975)：長距 離走に拄ける尿中成分変動の運動強度之の関連 性について。 九州体育学会沙錄，3(2)，1-2

5）小郷克敏，有江醇子，长尼愛彦，天本必太郎 林宏, 沢田芳男(1971)：ピルビン酸代謝に 関する研究 第 1 報 尿中ピルビン酸の足量 法。体質医研報， 22，77-82

6）小郷克钑, 有江醇子, 艮尾愛彦, 林宏, 緒 方 梨, 沢旧芳男(1975)：ピルビン酸代謝に関 する研究 第 4 報 自転車エルゴメータ一負荷 による尿中ピルビン酸とクエン酸の関係につい て。体領医研報，25，99-104

7) Philip D. Gollnick and Lars Hermansen(1973) : Biochemical adaptation to exercise : Anaerobic metabolism in exercise and sport sciences reviews Vol. 1 Ed. Jack H. Wilmore, Academic Press, New York and London. p. 1-43

8) R. Margaria, H.T. Edward and D.B. Dill (1933) : The possible mechanism of contracting and paying the oxygen debt and the role of lactic acid in musculal contraction. Amr. J. Physiol. 106, 689-715

9) T.E. Friedemann, C.J. Barborka (1941) : The 
siginificance of the ratio of lactic to pyruvic acid in the blood after exercise. J. Biol. Chem., 141, 993-994

10）山㥓省一，青木純一郎(1977）：長距灕走者の競
技記録之無酸䌽的能力. 体力科学, 26, 87-95

11) Adrian C. Kuyper and H.A. Mattill (1933) : Some aspects of citric acid metabolism. J. Biol. Chem., 103, 51-60 